\title{
Podocarpo, a plant of ornamental interest: asexual propagation
}

\author{
Fernanda Jaqueline Menegusso ${ }^{1}$, Fabíola Villa ${ }^{1 *} \mathbb{D}$, Daniel Fernandes da Silva ${ }^{1} \mathbb{D}$, Tatiane Eberling ${ }^{l}$, \\ Giovana Ritter ${ }^{1}$, Maria Cristina Copello Rotili ${ }^{2}$
}

$10.1590 / 0034-737 X 202168060005$

\begin{abstract}
The objective of this study was to evaluate the potential of rooting of podocarpos cuttings in function of the number of leaves, concentrations of IBA and phytorregulators, application methods and cutting season. Two experiments were carried out under weaning conditions, in a factorial scheme containing 3 replicates of 15 cuttings, the first with 4 concentrations of IBA, 3 leaves at the cuttings and 2 seasons. These were removed in August/2016 and January/2017, prepared with $10 \mathrm{~cm}$ in length and immersed in solutions for $10 \mathrm{~s}$. In the second experiment three types of phytoregulators and 2 application forms were tested (slow and quick immersion). Cuttings were prepared in the same manner as in the first experiment, maintaining 4 leaves. The bases of the cuttings were immersed for $10 \mathrm{~s}$ and $24 \mathrm{~h}$ in the solutions, then taken to root. After 100 days of experimentation, it was concluded that cuttings collected in the summer had a higher percentage of rooting, 4 leaves and IBA concentration should be maintained between 750 and $800 \mathrm{mg} \mathrm{L}^{-1}$. The best form of application of phytoregulator is by rapid immersion.
\end{abstract}

Keywords: Podocarpus macrophyllus (Thunb.) D. Don; landscaping; cutting; plant growth regulator.

\section{INTRODUCTION}

The podocarp is classified as a gymnosperm, belonging to the family Podocarpaceae and to the genus Podocarpus L'Hér. ex. Pers., being its species Podocarpus macrophyllus (Thunb.) Sweet (synonym Taxus macrophylla Thunb.) with center of origin in China and Japan (Lorenzi \& Souza, 2013). The genus is widespread in these countries, as well as in parts of Southeast Asia, being used in Japan as a bonsai and cultivated as a hedge (Farjon, 2010). Is also popularly known as buddha pine and is widely used as an ornamental plant, characterizing a columnar shape little tree (Mondin et al., 2010).

Subtropical frost tolerant plant and containment prunings for topiary purposes, its cultivation can be done directly on the soil, preferably fertile and humid, with good drainage, growing well in full sun or partial shade. The propagation is by seeds, however, there is a difficulty in obtaining it, besides the lack of uniformity in obtaining seedlings caused by genetic variability. An alternative to the sexual multiplication is cutting (Farjon, 2010).

The use of cutting as an alternative allows to obtain large quantity of seedlings from a single plant, in a short time, being a technique of low cost and easy execution. However, it becomes unfeasible when the species presents low genetic potential of rooting, resulting in few seedlings (Fachinello et al., 2005). In the work carried out by Monserrath et al. (2007), the production of seedlings of Podocarpus oleifolius and Prumnopitys montana was made from apical cuttings of young plants, since the use of medium cuttings of these species did not obtain desired success in rooting.

Among the factors that may affect the rooting of cuttings are the internal factors, such as the physiological condition of the mother plant and its age, type of cutting, time of year of picking, among others. As external factors, it is possible to mention temperature, light, humidity,

Submitted on April $20^{\text {th }}, 2020$ and accepted on March $23^{\text {th }}, 2021$.

${ }^{1}$ Universidade Estadual do Oeste do Paraná (Unioeste), Centro de Ciências Agrárias, Marechal Cândido Rondon, Paraná, Brazil. fjmenegusso@hotmail.com; fvilla2003@hotmail.com; daniel_eafi@yahoo.com.br; tatiane_eberling@hotmail.com; rittergiovana@gmail.com

${ }^{2}$ Colégio Agrícola Estadual de Palotina (CAEP), Departamento de Educação, Palotina, Paraná, Brazil. mcrotili@hotmail.com

*Corresponding author: fvilla2003@hotmail.com 
substrate and conditioning of the branches before cutting. The position of the stem in the branch, its degree of lignification, quantity of reserves, type of substrate, genotype, sanitary conditions of the mother plant may also influence rooting, also stressing that the results can be potentiated with or the use of phytoregulators (Hartmann et al., 2011).

The use of phytoregulators has the purpose of inducing the rhizogenic process, increasing the percentage of cuttings that form roots, the number and quality of the roots formed and the uniformity in rooting. Indolbutyric acid (IBA), which has been the most widely used auxin, is photostable, localized, persistent, non-toxic in a wide range of concentrations and not degraded by biological action. In addition, this product is poorly mobile at the cutting, staying longer at the application site. Other phytoregulators can be used such as naphthalene acetic acid (NAA) and indoleacetic acid (IAA) (Fachinello et al., 2005).

These synthetic products can be worked in the form of talc or in solution. When used in solution, it can be diluted, which corresponds to a solution whose concentration ranges from 20 to $200 \mathrm{mg} \mathrm{L}^{-1}$. The cutting base should be held in contact for a longer immersion time in the solution, usually $24 \mathrm{~h}$, in a shaded location. Another way to use the solution is concentrated, which corresponds to concentrations ranging between 200 and $10,000 \mathrm{mg} \mathrm{L}^{-1}$ and should remain in contact with the base of the cutting for a shorter time, around $5 \mathrm{~s}$.

Ferreira et al. (2009) working with diluted solutions and concentrated at different times of the year for semihardwood cuttings of Sapium glandulatum (Vell.) Pax obtained that treatments with diluted solutions did not show an effect on rooting of cuttings, regardless of the concentration of IBA, with a high mortality rate, with the highest percentage observed in concentrated solutions. These results for diluted solutions may have occurred because of a characteristic of the species, which requires concentrated solutions.

It is important to emphasize that exposure for a longer time, as well as the use of very high concentrations, can cause phytotoxic effects, such as inhibition of bud growth, yellowing and leaf fall, or even death of the cuttings (Hossain et al., 2019). In view of the above, the objective of this work was to evaluate the potential of rooting of podocarp cuttings in function of the number of leaves, IBA concentration, cutting time and also the rooting potential of the cuttings using phytorregulators in 2 application methods.

\section{MATERIAL AND METHODS}

Two experiments were carried out in the sequence, both developed at the Protected Cultivation and Biological Control Station "Professor Doctor Mário Cesar Lopes", belonging to the Experimental Station of Horticulture and Protected Culture of Unioeste, Campus Marechal Cândido Rondon (PR), under geographic coordinates of latitude $24^{\circ} 33^{\prime} 22^{\prime \prime} \mathrm{S}$ and longitude $54^{\circ} 03^{\prime} 24^{\prime \prime} \mathrm{W}$, and altitude of approximately $400 \mathrm{~m}$.

Both experiments were conducted under screen conditions with $50 \%$ shading. For the first experiment, the experimental design was a randomized block design with a $4 \times 3 \times 2$ factorial design [0, 500, 1000 and $1500 \mathrm{mg} \mathrm{L}^{-1}$ of indolebutyric acid (IBA) x 4, 6 and 8 x 2-leaf cuttings (end of winter-August/2017 and summer-January/2018)], resulting in 24 treatments, containing 3 replicates and 15 cuttings per replicate, totaling 1080 cuttings.

To prepare the solution of the phytoregulator, the IBA was weighed on a precision scale and then diluted in $0.1 \mathrm{~L}$ of ethyl alcohol hydrated and added with $0.1 \mathrm{~L}$ of distilled water, resulting in $0.2 \mathrm{~L}$ of the final concentrations (500, 1000 and $1500 \mathrm{mg} \mathrm{L}^{-1}$, respectively).

The matrix plants were purchased from ornamental plant producers in the municipality of Marechal Cândido Rondon, transplanted to $12 \mathrm{~L}$ polyethylene containers containing a mixture of latosol, sand and organic matter $(1: 1: 1, \mathrm{v} / \mathrm{v} / \mathrm{v})$, acclimatized in nursery for 90 days and with relevant cultural practices (fertilization, irrigation and pest and disease care).

With the aid of a pruning shear branches were removed from these matrix plants as a whole. From these branches, the cuttings, prepared with $10 \mathrm{~cm}$ in length, were discarded, and the remaining 4,6 or 8 leaves per cutting were maintained according to the treatment. Then the bases of the cuttings were immersed for $10 \mathrm{~s}$ in the previously prepared IBA solution. For the control treatment (without IBA), the bases of the cuttings were immersed only in distilled water.

For the second experiment, the experimental design was randomized blocks, in a $3 \times 2$ factorial scheme [ 3 types of phytoregulators (IBA, NAA and IAA) x 2 application forms (slow immersion and quick immersion)], resulting in 6 treatments, containing 3 replicates and 15 cuttings, totalizing 270 cuttings. The cuttings were removed from the matrix plants in december 2016 and prepared in the same manner as in the first experiment, with 4 leaves per cutting and discarding the apical portion.

For the preparation of the solutions containing IBA, IAA and NAA, each of the phytoregulators to be tested according to the previously established treatments were weighed into an analytical precision balance, followed by slow immersion, dilution of the phytoregulators in $0.25 \mathrm{~L}$ of ethyl alcohol hydrated at $46.2^{\circ}$ G.L., the volumes were filled with water to $0.5 \mathrm{~L}$ after complete dilution and for quick immersion the dilution of the phytoregulators occurred in $0.1 \mathrm{~L}$ of the same alcohol as above, with volume subsequently supplemented 
with water to $0.2 \mathrm{~L}$ after the total dilution. In this way a final solution of 200 and $1000 \mathrm{mg} \mathrm{L}^{-1}$ concentration of each phytoregulator was obtained for slow and quick immersion, respectively.

For the rapid immersion treatment, the bases of the cuttings were immersed for $10 \mathrm{~s}$ in the previously prepared solutions of phytoregulators and in the slow immersion treatment, they were kept immersed for $24 \mathrm{~h}$ in the solutions. In both experiments, immediately after the treatments, the cuttings used were arranged in a masonry bed containing medium texture sand, which was previously disinfected using $1 \mathrm{~L}$ of sodium hypochlorite diluted in $10 \mathrm{~L}$ of water and distributed by the extension of the bed with the aid of a watering can.

The visual control of pests and diseases, both in the parent plants and in the removed cuttings, was carried out weekly, and when necessary, agricultural pesticides were used. The active principle used was Chlorpyrifos and also mineral oil. Irrigation was carried out daily by a sprinkler irrigation system, operated for $5 \mathrm{~min}$ and average intervals of $1 \mathrm{~h}$, with a flow rate of $1.17 \times 10^{-8} \mathrm{~m}^{3} \mathrm{~s}^{-1}$. The mean temperature during the experiment was $22.4{ }^{\circ} \mathrm{C}$ and the relative humidity was $73.14 \%$.

After 100 days of experimentation, the percentage of rooted and callous cuttings, number of roots and length of the largest root $(\mathrm{cm})$ were evaluated in each of the two experiments. Within each replicate containing 15 cuttings, 5 cuttings were randomly analyzed. These had the roots thoroughly washed in running water and dried on paper towel. For the variables that involved percentage (rooted cuttings and chalked cuttings) the count was made and then the percentage was calculated. For length of the largest root, a graduated ruler was used for measurement.

The means of the qualitative variables obtained were submitted to the analysis of variance, and were compared by Tukey's test, $5 \%$ error probability and the mean of the quantitative variables submitted to the regression using the statistical software Sisvar (Ferreira, 2011). The data related to the number of leaves and roots were transformed to $\log (\mathrm{x}+0.5)$.

\section{RESULTS AND DISCUSSION}

For the first experiment, significant interaction was observed only for times $\mathrm{x}$ number of leaves, times $\mathrm{x}$ concentration of IBA and number of leaves at the cutting $\mathrm{x}$ concentration of IBA. Table 1 shows the significant interaction between seasons $x$ number of leaves.

It was noted that, regardless of the number of leaves remaining at the time of cutting, there was no difference within the seasons of staking. However, comparing the seasons, cuttings removed in the summer presented higher rhizogenic potential, independently of the number of leaves. The results found in this work corroborate Bischoff et al. (2017), who also verified that the rooting of cuttings of whiting is independent of the number of leaves present.

The presence of leaves in semilenous or herbaceous cuttings may favor rooting, probably due to the production of rooting cofactors in these organs. On the other hand, there is an increase in the transpiration surface, which indicates a need for greater nebulization care (Fachinello et al., 2005). Although there is no statistical difference between the number of leaves, it is recommended to avoid excessive removal in the preparation of the cuttings, considering that this practice can facilitate the attack of pathogens, due to the injuries. This process also makes the preparation costly, due to the need for more labor and time (Penso et al., 2016).

This result is based on the greater vegetative growth presented in this period (summer), facilitating root growth in general (Fachinello et al., 2005). Similar situation was found by Pivetta et al. (2012) working with Nerium oleander L. cuttings, which verified that the percentage of rooting of cuttings collected in the summer was also higher. Associated with the vegetative growth, greater production of free auxins is found in apical meristems and young leaves, being the main sites of hormone synthesis (Taiz et al., 2017).

For rooted cuttings, the interaction between cutting seasons and IBA concentrations is observed in Figure $1 \mathrm{~A}$, with the cuttings being removed in the summer which had greater rooting when compared to the cuttings collected in the winter, independent of the concentration of phytoregulator used.

Podocarp cuttings removed in the winter did not present significant difference in the percentage of rooting in the IBA concentrations tested, as verified in the work of Preti et al. (2012), with Physocalymma scaberrimum Pohl. cuttings taken between May and August treated with IBA. In this work, cuttings removed in the summer obtained better results when treated with $783.00 \mathrm{mg} \mathrm{L}^{-1}$, decreasing in a quadratic form after this concentration, indicating possible phytotoxicity of the phytorregulator.

Table 1: Percentage of rooting of podocarp cuttings with different numbers of leaves and seasons for do cuttings

\begin{tabular}{lccc}
\hline Seasons for & \multicolumn{3}{c}{ Number of leaves } \\
\cline { 2 - 4 } do cuttings & $\mathbf{4}$ & $\mathbf{6}$ & $\mathbf{8}$ \\
\hline Winter & $10.00 \mathrm{bA}^{*}$ & $9.46 \mathrm{bA}$ & $13.86 \mathrm{bA}$ \\
Summer & $75.00 \mathrm{aA}$ & $80.00 \mathrm{aA}$ & $73.33 \mathrm{aA}$ \\
\hline $\mathrm{CV}(\%)$ & \multicolumn{3}{|c}{16.78} \\
\hline
\end{tabular}

* Means followed by the same lowercase letter do not differ from each other in the column and uppercase letter in the row, by Tukey's test, at $5 \%$ probability of error. Transformed data for $\log (x+0.5)$. 
Similar results were found for other ornamental species, such as Malvaviscus arboreus Cav. and Hibiscus sp. L, presenting better rooting percentages with IBA use (from 10.46 to $31.76 \%$ for Malvaviscus arboreus and from 70 to 95.60\% of rooting for Hibiscus sp. L.), although in high concentrations the number of rooted cuttings has decreased (Loss et al., 2009, Pizzatto et al., 2011), fact that the authors also attributed auxin phytotoxicity.

It is possible to observe that the use of IBA promoted an increase in the number of rooted cuttings in relation to the treatment that did not use the phytorregulator, and it can be observed that when the endogenous auxin content is insufficient, the application of synthetic auxin is important to promote a hormonal balance which favors rooting of cuttings (Fragoso et al., 2017).

Figure $1 \mathrm{~B}$ shows a significant interaction between number of leaves and IBA concentrations, with a higher percentage of rooting in cuttings containing 4 leaves and treated with $775 \mathrm{mg} \mathrm{L}^{-1}$ of IBA. In order for there to be an efficient rooting, there must be a balan- ce between the amount of auxin and carbohydrates at the cutting, which is why the leaves are important organs, because they have the capacity to synthesize auxins and at the same time produce and store reserves, as well as being responsible by the synthesis of phenolic compounds that possibly aid in rooting and survival of cuttings (Pacheco \& Franco, 2008). However, caution is needed because leaves on cuttings can also impair rooting due to sweating and excessive dehydration (Silva et al., 2015).

Considering the above statements, 4-leaf cuttings may have been better because they offered a sufficient amount of carbohydrates for cutting maintenance during the rooting period, together with a balanced transpiration surface, being complemented by the exogenous auxin up to the maximum calculated point $\left(775 \mathrm{mg} \mathrm{L}^{-1}\right)$, an amount considered ideal for the species.

Figure 2 shows the results of the callus cuttings, with significant interaction for number of leaves and IBA concentrations.
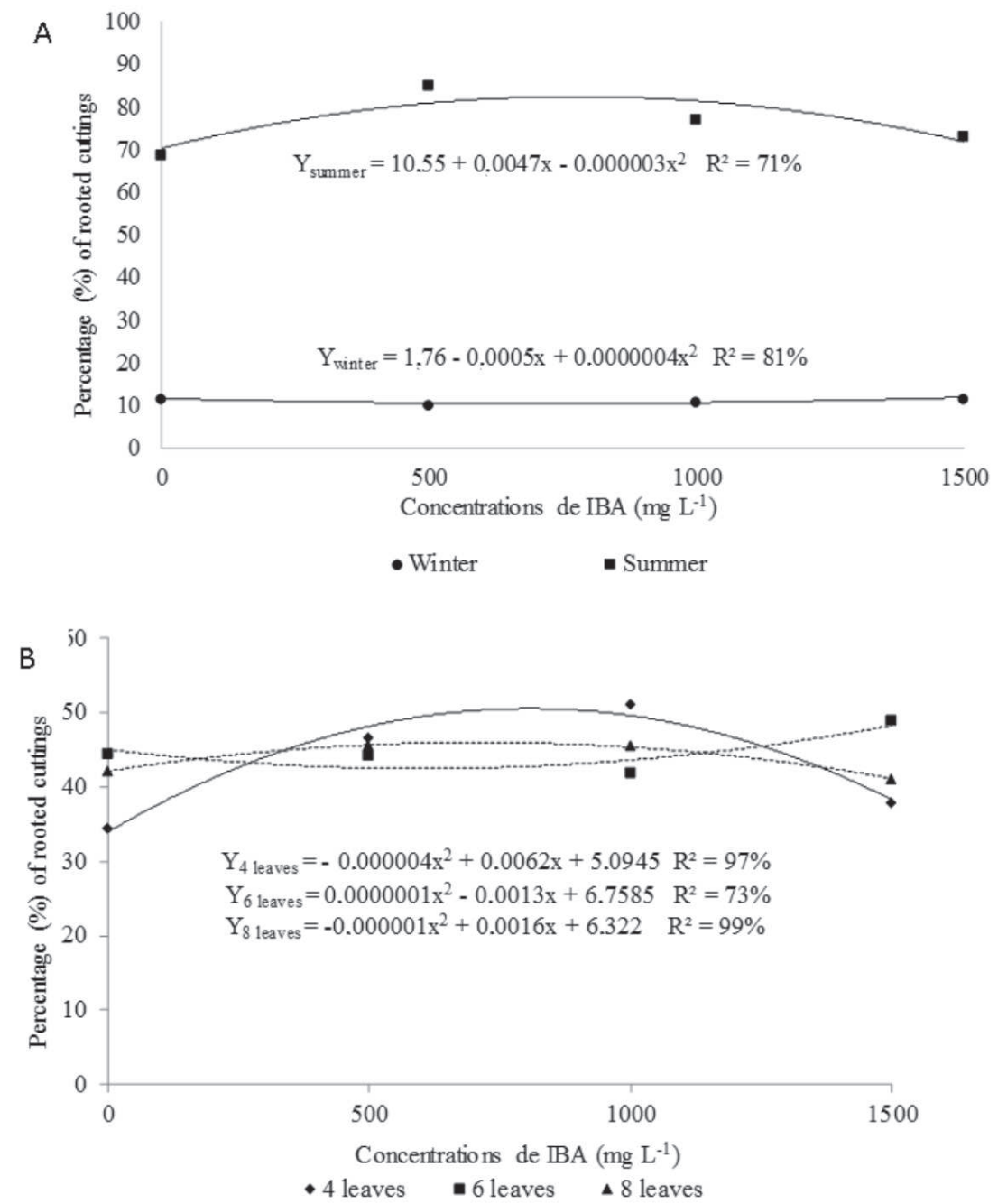

Figure 1: A. Percentage of rooted cuttings as a function of cutting seasons associated with IBA concentrations $\left(\mathrm{mg} \mathrm{L}^{-1}\right)$. B. Percentage of cuttings rooted according to the number of leaves associated with IBA concentrations $\left(\mathrm{mg} \mathrm{L}^{-1}\right)$. 
Better results with less number of callous cuttings can be observed in cuttings containing 4 leaves associated with $625 \mathrm{mg} \mathrm{L}^{-1}$ of IBA. The low percentage of callous cuttings probably occurred due to the greater rooting of cuttings containing 4 leaves, in concentration near IBA. Similar result was found by Lima et al. (2011), with an inverse relationship between callus formation and rooting of Camellia sinensis (L.) Kuntze cuttings.

In cuttings containing 6 leaves, a great number of calli were found (Figure 2), but, antagonistically, a lower presence of roots in these stakes (Figure 1B). The presence of callus in the base of the cuttings presented an inverse relationship with root formation. Although during the rhizogenesis, one of the phases for the formation of new adventitious roots is the cellular multiplication, characteristic also in the development of calluses, both are independent events, that can occur simultaneously without having a direct relation between the formation of calluses and rooting (Hartmann et al., 2011, Silva et al., 2015).

The leaves have the function in the rooting of cuttings related to photosynthesis and supply of nutrients, auxins and rooting cofactors, which are taken to the base of the cutting. However, the leaves represent a transpiratory surface, so nebulization is used and only 2 or 3 leaves are kept at the cutting (Lima et al., 2011, Fachinello et al., 2005).

The fact that the cuttings with the highest number of leaves present a higher percentage of callus may be related to the addition of the exogenous auxin, since by the amount of leaves present, this phytoregulator would already be in sufficient quantity. Fachinello et al. (2005) assure that the increase of the exogenous auxin concen- tration applied in cuttings causes a root stimulating effect up to a maximum value, from which any addition of auxins has an inhibitory effect. This inhibition in the formation of roots in cuttings with larger leaves may be a hormonal alteration caused by the supply of exogenous auxin, since the adequate content of exogenous auxin for rooting depends on the concentration of auxin present in the tissue (endogenous) (Paulus et al., 2014).

Similar results were found in olive cuttings by Penso et al. (2016). In the experiments carried out in June and March, when comparing the number of leaves, the cuttings that had 4 leaves had a higher percentage of callus, close to $100 \%$, when compared to those that did not contain or contained 2 leaves. This leads to the understanding that the maintenance of the leaves and metabolic activities increases the formation of calluses, regardless of the concentration of IBA, evidencing that the concentration of endogenous auxin in these cases is sufficient to stimulate tissue dedifferentiation and consequent callus formation.

Observing the number and length of roots, it was observed that both reached superior results when the cutting was performed in the summer in detriment to the winter (Table 2), corroborating Pivetta et al. (2012) when them studied Nerium oleander L. cuttings, removed in winter and summer, observed that the summer cuttings reached average number and average length of upper roots. This fact can be explained by the reduced concentration of rooting promoting substances present in the cuttings during the winter period, in relation to the vegetative development season (summer) (Vignolo et al., 2014).

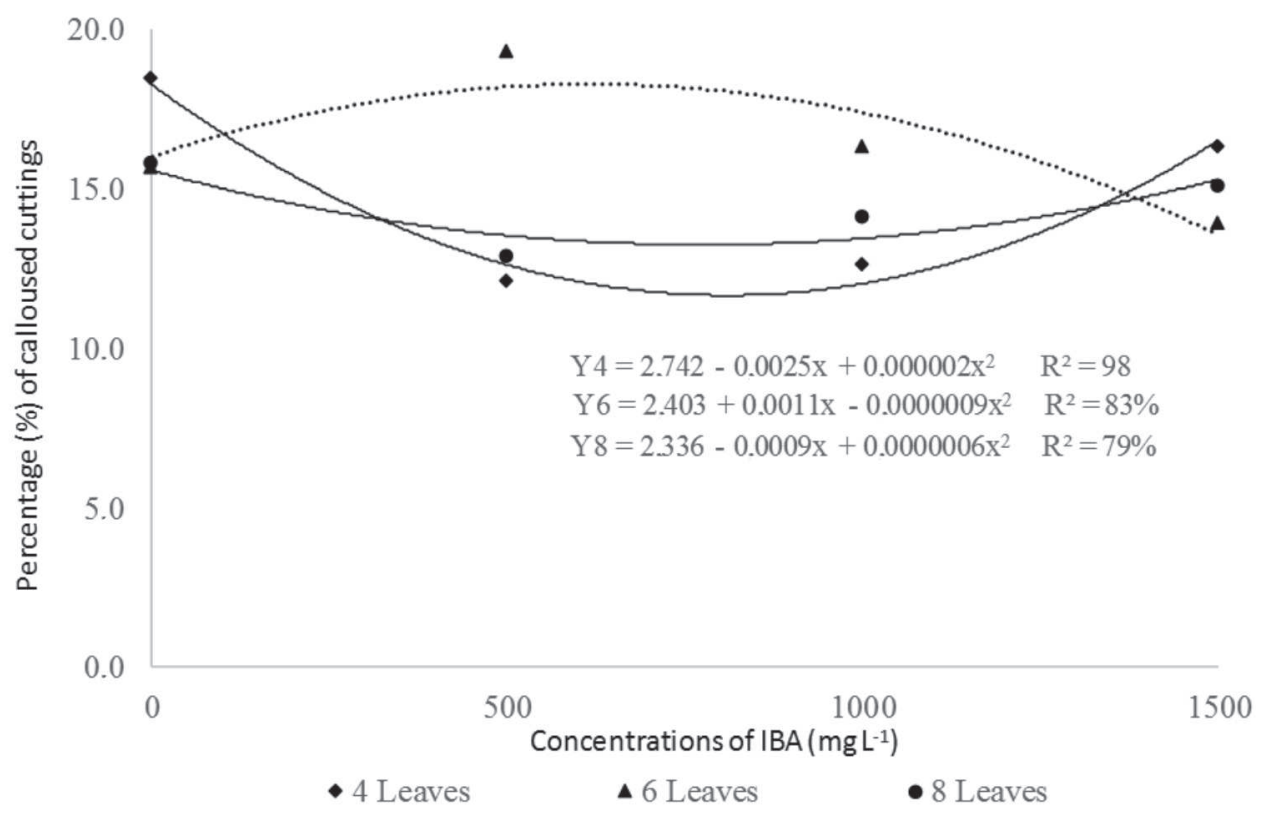

Figure 2: Percentage of callus cuttings as a function of number of leaves and IBA concentrations. 
Table 3 shows the results for percentage of rooting, percentage of callous cuttings, average number of roots per stem and average length of the largest root, referring to the second experiment. Significance was verified only for the type of immersion, regardless of the type of phytoregulator used.

For rooting (\%) of podocarp cuttings submitted to these treatments, a better performance was observed when using quick immersion, presenting $57.06 \%$ of rooting, whereas, when using slow immersion, no rooting was obtained (Table 3), visualizing oxidation of the cuttings. The amount of the absorbed phytoregulator depends on the environmental conditions surrounding the site, cutting type and species. The results found may be characteristic of the species, demonstrating that it requires higher concentrations of phytorregulator (Fachinello et al., 2005).

For callous cuttings, it was observed a better performance with slow immersion, with $0 \%$ of callous cuttings, whereas in quick immersion it reached $41.46 \%$ of callousing. Fachinello et al. (2005) cite that rooting and calebing are independent events, and the formation of callus is not a guarantee of the formation of adventitious roots, so there is no direct relationship in rooting and calebing. In this way it is important to have a lower percentage of callousing and greater rooting. However, it should be noted that the cuttings submitted to the slow immersion treatment showed oxidation.

It is important to note that the stimulatory effect of roots from the increase of the exogenous auxin concentration is given up to a maximum limit, from which any increase leads to an inhibitory effect, phytotoxicity

Table 2: Number of roots and length of the largest root in podocarp seedling rooted in two seasons

\begin{tabular}{lcc}
\hline $\begin{array}{l}\text { Seasons for } \\
\text { do cuttings }\end{array}$ & $\begin{array}{c}\text { Number } \\
\text { of roots }\end{array}$ & $\begin{array}{c}\text { Length of } \\
\text { thelargest root }(\mathbf{c m})\end{array}$ \\
\hline Winter & $8.49 \mathrm{~b}^{*}$ & $2.02 \mathrm{~b}$ \\
Summer & $11.46 \mathrm{a}$ & $10.47 \mathrm{a}$ \\
\hline $\mathrm{CV}(\%)$ & 29.71 & 21.13 \\
\hline
\end{tabular}

* Means followed by the same lowercase letter do not differ in the column, by Tukey's test, at $5 \%$ probability of error. Transformed data for $\log (\mathrm{x}+0.5)$.
(Fachinello et al., 2005). This may justify the oxidation of the treated cuttings in slow immersion because the concentration used in association with the alcohol and the time of exposure of the stake to this solution may have favored the necrosis.

Ferreira et al. (2009), when working with cuttings of Sapium glandulatum (Vell.) Pax in slow immersion (16 hours) of phytoregulator solution with concentrations of 200 and $400 \mathrm{mg} \mathrm{L}^{-1}$ obtained $0 \%$ of rooted cuttings and calloused cuttings, with $100 \%$ dead cuttings.

The number of roots per stem observed when using the quick immersion was 6.06 and, once again affirming the superiority of this method of application of phytorregulator. For Sequoia sempervirens (D. Don) Endl., which belongs to the same order as the Podocarpus macrophyllus (Thunb.) Sweet, pinales, cuttings may present problems in rooting and low root production, which may the survival of seedlings.

Considering that this is a gymnosperm, it can be said that the evaluation of the experiment in 100 days and the number of roots reached in the treatment of the study species, podocarp, was satisfactory conditions.

The length of the largest root was $3.36 \mathrm{~cm}$ in quick immersion, while in slow immersion the cuttings did not present root formation. Tofanelli et al. (2003) found positive results for use of the quick immersion method, in which the length of the largest root was superior by this method compared to the slow immersion method for peach cuttings. Another reason for the slow immersion method to result in pile oxidation and non-rooting and non-gaging may be the effect of the environment during the slow immersion treatment, since the absence of a misting system, for example, may have favored the dehydration of the cuttings and subsequent excessive absorption of the IBA solutions by the ones that, instead of the regulator stimulate, inhibited the rooting.

Considering the few scientific studies found in the literature, future research may be carried out with podocarp, mainly in the formation and preparation of seedlings, as related to the forms of use (talc and solution), type of phytorregulator and other intrinsic and extrinsic factors that interfere in the cutting, as well as monitoring the formation of seedlings.

Table 3: Percentage of rooting, percentage of callus cuttings, average number of roots per cutting and average length of the largest root in podocarp seedling rooted with 2 types of immersion in solutions of phytorregulators

\begin{tabular}{lcccc}
\hline Type of immersion & $\begin{array}{c}\text { Rooting } \\
(\boldsymbol{\%})\end{array}$ & $\begin{array}{c}\text { Calloused cuttings } \\
(\boldsymbol{\%})\end{array}$ & $\begin{array}{c}\text { Number of } \\
\text { roots/cutting }\end{array}$ & $\begin{array}{c}\text { Length of the largest } \\
\text { root /cutting }(\mathbf{c m})\end{array}$ \\
\hline Quick & $57.06 \mathrm{a}^{*}$ & $41.46 \mathrm{a}$ & $6.06 \mathrm{a}$ & $3.36 \mathrm{a}$ \\
Slown & $0.00 \mathrm{~b}$ & $0.00 \mathrm{~b}$ & $0.00 \mathrm{~b}$ & $0.00 \mathrm{~b}$ \\
\hline $\mathrm{CV}(\%)$ & 14.12 & 17.61 & 12.17 & 14.60 \\
\hline
\end{tabular}

*Means followed by the same lowercase letter do not differ in the column, by Tukey's test, at 5\% probability of error. 


\section{CONCLUSIONS}

Podocarp cuttings collected in the summer showed better rooting. In the cuttings, 4 leaves should be kept and the best IBA concentration for rooting was in the range of 750 to $800 \mathrm{mg} \mathrm{L}^{-1}$.

The best way to apply the phytoregulator is by rapid immersion.

\section{ACKNOWLEDGEMENTS, FINANCIAL SUPPORT AND FULL DISCLOSURE}

To CAPES for granting a scholarship. We have no conflict of interest to declare.

\section{REFERENCES}

Bischoff AM, Vendramim DW, Gomes EN, Zuffellato-Ribas KC, Engel ML \& Maggioni RA (2017) Enraizamento de estacas de erva-baleeira em função de diferentes concentrações de ácido indol butírico e número de folhas. Revista de Ciências Agroveterinárias, 16:41-47.

Fachinello JC, Hoffmann A \& Nachtigal JC (2005) Propagação de plantas frutíferas. Brasília, EMBRAPA. 133p.

Farjon AA (2010) Handbook of the world's conifers. Boston, Brill. p.857-859.

Ferreira DF (2011) Sisvar: a computer statistical analysis system. Ciência \& Agrotecnologia, 35:1039-1042.

Ferreira BGA, Zuffellato-Ribas KC, Carpanezzi AA, Tavares FR \& Koehler HS (2009) Metodologias de aplicação de AIB no enraizamento de estacas semilenhosas de Sapium glandulatum (Vell.) Pax. Revista Brasileira de Plantas Medicinais, 11:196-201.

Fragoso RO, Stuepp CA, Rickli HC, Zuffelatto-Ribas KC \& Koehler HS (2017) Maximum efficiency concentration of indole butyric acid in promoting the rooting of Japanese Flowering Cherry. Ciência Rural, 47:1-6.

Hartmann HT, Kester DE, Davies Junior FT \& Geneve RL (2011) Plant propagation: principles and practices. $9^{\text {th }}$ ed. New Jersey, Prentice Hall. 1024p.

Hossain MA, Islam MA, Azad MAK, Rahman MM, Shumi W \& Shukor NAA (2019) Propagation of an endangered gymnosperm tree species (Podocarpus nerifolius D. Don.) by stem cuttings in non-mist propagator. Pertanika Journal of Tropical Agricultural Science, 42:237-250.

Lima JD, Lima APS, Bolfarini ACB \& Silva SHM (2011) Enraizamento de estacas de Camellia sinensis L. em função da época de coleta de ramos, genótipos e ácido indolbutírico. Ciência Rural, 41:230-235.

Lorenzi H \& Souza HM (2013). Plantas ornamentais no Brasil: arbustivas, herbáceas e trepadeiras. $3^{\text {rd }}$ ed. Nova Odessa, Plantarum. p.1088.

Loss A, Teixeira MB, Santos TJ, Gomes VM \& Queiroz LH (2009) Indução do enraizamento em estacas de Malvaviscus arboreus Cav. com diferentes concentrações de ácido de ácido indolbutírico (AIB). Acta Scientiarum, 31:269-273.

Mondin CA, Eggers L \& Ferreira PMA (2010) Catálogo Ilustrado de Plantas - Espécies Ornamentais da PUCRS. Porto Alegre, EDIPUCRS. p.127.

Monserrath CS, Cueva DV, Aguirre NM \& Gunter S (2007) Propagación a nivel de invernadero y estudio de regeneración natural de dos especies de Podocarpaceas en su hábitat natural. Bosques Latitud Cero, 3:26-29.
Pacheco JP \& Franco ETH (2008) Substratos e estacas com e sem folhas no enraizamento de Luehea divaricata Mart. Ciência Rural, 38:1900-1906.

Paulus D, Valmorbida R, Toffoli E \& Paulus E (2014) Propagação vegetativa de Aloysia triphylla (L'Hér.) Britton em função da concentração de AIB e do comprimento das estacas. Revista Brasileira de Plantas Medicinais, 16:25-31.

Penso GA, Sachet MR, Maro LAC, Patto LS \& Citadin I (2016) Propagação de oliveira 'Koroneiki' pelo método de estaquia em diferentes épocas, concentrações de AIB e presença de folhas. Revista Ceres, 63:355-360.

Pivetta KFL, Pedrinhi DR, Fávero S, Battista GS \& Bachin M (2012) Época de coleta e ácido indolbutírico no enraizamento de estacas de espirradeira (Nerium oleander L.). Revista Árvore, 36:17-23.

Pizzatto M, Wagner Júnior A, Luckmann D, Pirola K, Cassol DA \& Mazaro SM (2011) Influência do uso de AIB, época de coleta e tamanho de estaca na propagação vegetativa de hibisco por estaquia. Revista Ceres, 58:487-492.

Preti EA, Yamamoto LY, Cardoso C, Aquino GS, Paes VS, Assis AM, Machado MH, Neves CSVJ \& Roberto SR (2012) Estaquia de Resedá-Nacional (Physocalymma scaberrimum Pohl.) em diferentes substratos e concentrações de AIB. Ciência Florestal, 22:377-383.

Silva A, Reges NPR, Melo JK, Santos MP \& Sousa CM (2015) Enraizamento de estacas caulinares de ixora. Ornamental Horticultur, 21:201-208.

Taiz L, Zeiger E, Ian MM \& Murphy A (2017) Fisiologia e desenvolvimento vegetal. $6^{\text {th }}$ ed. Porto Alegre, Artmed. p.618.

Tofanelli MBD, Rodrigues JD \& Ono EO (2003) Método de aplicação do ácido indolbutírico na estaquia de cultivares de pessegueiro. Ciência \& Agrotecnologia, 27:1031-1037.

Vignolo GK, Picolotto L, Gonçalves MA, Pereira IS \& Antunes LEC (2014) Presença de folhas no enraizamento de estacas de amoreira-preta. Ciência Rural, 44:467-472. 